\title{
Creative Educational Practices for Inclusion of Gifted Children
}

\author{
Fernanda Hellen Ribeiro Piske, Tania Stoltz, Jarci Machado \\ Federal University of Parana, Curitiba, Brazil \\ Email: nandahellen@hotmail.com, tania.stoltz795@googlemail.com, jarcimachado.0202@gmail.com
}

Received 1 May 2014; revised 26 May 2014; accepted 8 June 2014

Copyright $@ 2014$ by authors and Scientific Research Publishing Inc.

This work is licensed under the Creative Commons Attribution International License (CC BY).

http://creativecommons.org/licenses/by/4.0/

cC) (i) Open Access

\begin{abstract}
Inclusion of gifted students depends on several aspects to happen in the school context, and one of the most important aspects to include these children at school is creative educational practices. Teaching with art is a good possibility to make children feel motivated to attend school. In the school context, the inclusion of these children could mean an important progress for science in various fields of knowledge. But many schools are still not prepared to attend gifted, and without even realizing it, they have exclusive and discouraging educational practices for attending these students. In this sense, this research aims to emphasize the importance of good teacher training for developing creativity of gifted students at school. The method of this research was based on a study of national and international bibliographic researches focused on the area of High Abilities /Giftedness, inclusive education and Creativity. It is concluded that the inclusion of gifted students depends on a good teacher work developing creativity during their classes. The teacher as a principal mediator of the teaching-learning process should provide creative educational practices emphasizing artistic activities such as painting, drawings, theater among other practices for attending gifted children. Only in this way can these students develop their curiosity and desire to attend classes at school.
\end{abstract}

\section{Keywords}

Creativity, High Abilities/Giftedness, Inclusion

\section{Introduction}

The attendance of gifted is a challenge for many schools. The inclusion of these children is very difficult because many teachers are not prepared to develop an interesting and creative teaching to attend their special needs. It is important to consider "every human being as an integral and different individual because each person has 
his/her unique characteristics of personality” (Piske, Stoltz, \& Machado, 2014: p. 348).

Unfortunately many schools are still not prepared to attend gifted children and they offer exclusive and discouraging educational practices for attending these students (Freitas, 2006). In this sense, the objective of this research is to highlight the importance of good teacher training for developing creativity of gifted children in the school context.

Piske $(2011,2013)$ explains that teaching done from the creative educational practices becomes more pleasurable and satisfying, and therefore during the process of inclusion teaching, the team needs to create emotional bonds so that gifted children can be motivated, have freedom of speech to develop their creativity in a stimulating environment and present successful interpersonal relationships in their surroundings (Stoltz \& Piske, 2012).

According to Piske \& Stoltz (2013) it is important that school know how to provide for gifted students an education that enables a good social and emotional development respecting their limits, their capabilities and their feelings. Each student is different and has many singularities. It is essential to accept their differences and allow their progress in the school context (Piske \& Stoltz, 2012, 2013).

Teacher training needs to consider important issues such as: analyzing, attending and enabling the improvement of the broad schooling processes, including the most diverse differences in school. It should have reflection about the characteristics, needs and specific pedagogical procedures for all the special needs that students present in the school context.

Bueno (2001: p. 15) indicates four major challenges that inclusive education requires in relation to the training of the teaching staff:

1) Solid theoretical training or appropriate training in relation to different processes and pedagogical procedures involving pedagogical knowledge and know how to do pedagogically;

2) Training that enable analyzing, attending and contributing to the improvement of the schooling processes of the many diverse differences, among them, disabled children that have been incorporated into the regular educational process;

3) Specific training on common characteristics of children with special educational needs, such as localized expressions of contradictory relations between society and minorities;

4) Training about the characteristics, specific pedagogical procedures for each of the special educational needs (Bueno, 2001: p. 15).

There are some challenges related to inclusive education that needs to be discussed by the school, teachers, families and the society. Pedagogical procedures should be in favor of a creative teaching to guarantee a quality education for students.

\section{Creative Practices to Attend Gifted Children at School}

It is essential to have creative educational practices to attend the special needs of gifted students, otherwise these children will have a repetitive teaching as their other classmates, so if there is no development of creativity there is no inclusion.

Piske (2013) emphasizes that it is not enough just identify students with high potential, it is important that the teaching staff promote a stimulating environment of creativity in their classes. This environment should arouse the curiosity and interest of students.

Wechsler (1998) points out some suggestions for teachers to develop the creativity of students, among them, it is possible to highlight:

- Encourage students to do their personal projects as a way to recognize their skills and talents;

- Encourage them to be inquisitive; enable students have different ideas of yours; provide opportunities for exploration of the environment, whenever possible let them leave the limited physical space of the classroom;

- Give chance to the students to propose questions and test their hypotheses, even if these questions seem inadequate or absurd at first; try to stimulate their curiosity to learn and discourage their memorization;

- Encourage the students to find the answers to the problems; give to the students the freedom to choose among different ways of solving a problem, diversifying the opportunities for a proposed activity; among other stimuli for developing creativity.

The school context includes many differences that require preparation of the teaching staff to work differently to attend the characteristics of each student. "So the ethical field of movement of inclusion is marked by the affirmation or negation of the each individual, accepted in his/her uniqueness, respected by the difference that 
makes him/her unique among all human beings” (Tunes, 2003: p. 10).

Several national and international studies (Alencar, 1986, 2007; Winner, 1998, 2000; Freeman \& Guenther, 2000; Delou, 2001, 2007; Virgolim, 2003; Maia-Pinto \& Fleith, 2004; Pérez, 2003, 2004; Freitas \& Negrini, 2008; Chagas \& Fleith, 2009 and other studies) indicate that the inclusion of gifted students depends on good training teachers for their progress in the school context.

Since inclusion depends on teachers training, these education professionals should reflect about their practices during their classes so that they could provide a teaching that include creative activities to develop creative potential of gifted children.

The inclusion of students with high potential has been happening in a very precarious way, mainly because of repetitive educational practices that don't develop creativity. Besides there is still a lack of financial resources and human resources to attend the special educational needs of these children who are looking for new challenges in the process of teaching and learning.

It is noteworthy that programs such as acceleration, enrichment curriculum should be implemented in schools, but it is perceived the lack of initiative to deploy them, and when these programs are offered at schools, in most cases, there are no suitable conditions to attend these children. Furthermore, the training of teachers is very spotty, causing frustration on many students and lack of interest to continue studying and learning by a repetitive method that provides no knowledge beyond that students already have.

Many gifted students prefer not come to school because they do not see an effective solution to attend their educational needs. To avoid this situation, "the formation of the special educator or of regular class must include programs that provide skills development that enable a professional of education be prepared to act in different and unique situations” (Freitas, 2006: p. 169).

\section{The Importance of Programs about Giftedness and Creativity}

Alencar (2001) points out that through an analysis of proposals and programs for gifted in Brazil, we can perceived that the amount of gifted students who have the opportunity to participate in a special program is greatly reduced. There is also a lack of understanding about what means intelligence, it should be perceived in various dimensions. On the other hand, students who have a special ability should receive a special service according to their needs. It happens many times the lack of attention to these students, the differential education of students with High Abilities/Giftedness has not received special attention by educational authorities.

Alencar, (1986, 2007), Freeman \& Guenther (2000), Virgolim (2003) point out that the training of some professionals of education is precarious and many teachers are not prepared to attend the needs of gifted students. Alencar (1986, 2001) explains that only few courses of Psychology offer subjects such as: Psychology of gifted student and Psychology of Creativity.

Giftedness and creativity are themes not mentioned in many courses of Psychology. Most of Pedagogy courses have no subject related to curriculum, education or programs about giftedness. "It is important that existing programs about giftedness continue attending gifted students education at all levels and types of teaching” (Alencar, 2001: p. 181).

In this sense, the school that offers specialized services to gifted students, should provide adequate attendance by teachers and by psychologists for these children with special educational needs so that they don't feel excluded by their own educational system.

However, it is possible to perceive that the presence of children with unique characteristics continue to mean a common worry for teachers who are unaware about the special needs that their students have, and when teachers identified these needs, they are not able to deal with this situation.

Consequently, these children feel excluded and discouraged to continue the process of teaching and learning. "Students with High Abilities/Giftedness are present in large numbers in schools and many times they are not perceived by their teacher and by their family” (Freitas \& Negrini, 2008: p. 282).

Guimarães (2007) explains that teachers need to have a good training and qualification in the area of giftedness, avoiding biases and inadequate ideas. They should participate in the identification phase, but also in developing a more flexible curriculum for gifted children.

\section{Creativity, Average Ability and Task Commitment to Define Giftedness}

Although this article highlight creativity as an essential aspect for the development of creative potential, gifted- 
ness can be defined by three fundamental aspects, such as: average ability, task commitment and creativity.

Renzulli \& Reis (1985) define in their model of the Three Rings, giftedness as the result of the interaction of three important aspects, namely: above average ability, task commitment and creativity. These aspects are present in some people under certain circumstances.

Renzulli \& Reis (1985) explain the difference between general abilities and specific abilities. General abilities are related to abstract thinking, processing information, integrating experiences, whereas specific abilities can be exemplified as perform in an activity and capacity to acquire knowledge. These authors define creativity as originality of thought, fluency and flexibility. And task commitment is related to motivation, perseverance and self-confidence of gifted children.

According to Alencar (2001) the types of giftedness can be determined by the specificity of the features and abilities of each individual associated with the cultural environment and the social demands where the person is inserted. It is necessary to create a welcoming and responsive environment that can attend the social and emotional needs of gifted individuals so that they can develop their potencials, talents and creativity.

We should reflect about the concept of training of the teaching staff through a significant and broad reflection because it is from a creative and innovative education that we can promote the development of potential and talent. Garcia (1999: pp. 21-22) explains that the training is presented in a complex and diverse phenomenon, there are only few conceptualizations, there are limitations about the dimensions and theories most relevant for our analysis. [...] In the first instance, training is perceived as conceptual reality, it is not identified and it is not diluted into other concepts that we also have, such as education, teaching, training, etc. Secondly, the concept of training includes a personal dimension of global human development that must be taken into account against other highly technical concepts. Thirdly, the concept of training has to do with the ability of training as well as will of training (Garcia, 1999: pp. 21-22).

Teacher training should include a teaching that has the power to change the school environment. But unfortunately it is not this way that it happens. Learning should occur as something that causes pleasure and satisfaction. Although the constant discussion about this subject in the daily school, some teachers don't have provided yet a learning that allows gifted students to understand true importance of the process of teaching and learning. "Learning has the power of transformation and it has been discussed extensively in daily life and academic environment” (Gasque \& Tescarolo, 2004: p. 36). However, the educational system needs to set goals so that learning be innovative and creative.

It is important that teachers perceive the school as a space for thinking human beings who share their experiences and move on toward new insights. They could value the knowledge learned by students during their students' lives, and help them to develop this knowledge further. It is essential that students get experience from their social and cultural backgrounds, and therefore this experience will become important knowledge. "The classroom is the place where there is a meeting of thinking individuals who share ideas, exchange experiences, tell stories, face challenges, break with the old things and seek new experiences” (Cerqueira, 2006: p. 32).

A school is no longer transmitting content and it becomes a reflective school if it has a compromised space with humanization, if it allows the dialogue among the individuals. This way, students could be helped broadly. For this, it would be necessary to know what students think, how and in what way they think, so we can finally help them overcome their difficulties.

The process of teaching and learning requires educational practices that recognize and attend the interests of students. It is not enough simply transmit content by a professional obligation. The education needs professionals who are committed to teaching and to share their knowledge with their students.

Unfortunately, a good teacher training is still desired. Actually, what is evident is a false training that generates individuals that don't reflect about reality that prevails in the capitalist world and they only worry about to update themselves.

\section{Pedagogical Practices}

Regarding pedagogical practices, it is possible to highlight its relevance by providing reflection for the future of professionals of education. Pedagogical practices are important especially in relation to gifted students, their education is a social investment, and if their talents are stimulated and developed productively, they can mean many contributions to society in several areas of knowledge (Brasil, 1999).

Therefore, the Specialized Educational Service for gifted students should be continuous, because this service can help these children to overcome their emotional, social and intellectual difficulties. It is emphasized the im- 
portance of each school offer inclusive practices that promotes the development of capabilities and talents through a challenging teaching.

da Silva \& Aranha (2005) emphasize that education should have an educational system that recognizes, respects and responds with pedagogical efficiency, each individual who it is inserted in the school context. Education could provide their transforming action with inclusive practices that attend all individuals.

It is important to highlight that the support from the school and the family for gifted students' education is essential, especially in such an unequal and exclusionary society. According to Rech \& Freitas (2005) it is necessary provide a welcoming environment, at home and also at school. Their family and their school could offer for these students: attention, love, understanding about their special needs, among other aspects that are essential in order that they develop their abilities properly.

It is necessary to promote favorable conditions for gifted students' education because if there is no incentive for these students, we are increasingly distant to become a developed country, which have its human resources to solve complex problems that we experience or that we can face in the future (Alencar, 2001).

\section{Conclusion}

It is important that teachers prepare activities that mean challenges for gifted students, and encourage these students to research about their area of interest. These students are looking for creative and innovative classes, so it is essential that the teaching staff avoid offering repetitive and monotonous teaching as it happens in most schools. Teachers could work with curriculum enrichment from artistic educational practices, such as the use of educational games, paintings, drawings, theater, literature, and other practices that develop imagination, fantasy and creativity of gifted students.

\section{References}

Alencar, E. M. L. S. (1986). Psicologia e educação de superdotado. São Paulo: EPU.

Alencar, E. M. L. S. (2001). Superdotados: Determinantes, educação e ajustamento. São Paulo: EPU.

Alencar, E. M. L. S. (2007). Características socioemocionais do superdotado: questões atuais. Psicologia em estudo, 12, 371378. http://www.scielo.br/pdf/pe/v12n2/v12n2a18.pdf

Brasil (1999). Ministério da Educação. Secretaria de Educação Especial. Programa de capacitação de recursos humanos do ensino fundamental: Superdotação e talento. Brasília: MEC/SEESP.

Bueno, J. G. S. (2001). Crianças com necessidades educativas especiais, política educacional e a formação de professores: Generalistas ou especialistas? http://www.educacaoonline.pro.br

Cerqueira, T. C. S. (2006). O professor em sala de aula: Reflexão sobre os estilos de aprendizagem e a escuta sensível. Psic, Revista de Psicologia da Vetor Editora, 7, 29-38.

Chagas, J. F., \& Fleith, D. S. (2009). Estudo comparativo sobre superdotação com famílias em situação socioeconômica desfavorecida. Revista Brasileira de Educação Especial, 15, 155-170. http://www.scielo.br/pdf/rbee/v15n1/11.pdf

Delou, C. M. C. (2001). Sucesso e fracasso escolar de alunos considerados superdotados: Um estudo sobre a trajetória escolar de alunos que receberam atendimento em salas de recursos de escolas da rede pública de ensino. Tese (Doutorado), São Paulo: Pontifícia Universidade Católica de São Paulo.

Delou, C. M. C. (2007). O papel da família no desenvolvimento de altas habilidades e talentos. In D. S. de. Fleith, \& E. M. L. S. de. Alencar (Eds.), Desenvolvimento de talentos e altas habilidades: Orientação a pais e professores. Porto Alegre: Artmed.

Freeman, J., \& Guenther, Z. C. (2000). Educando os mais capazes: Ideias e ações comprovadas. São Paulo: EPU.

Freitas, S. N. (2006). A formação de professores na educação inclusiva: Construindo a base de todo o processo. In: D. Rodrigues (Ed.), Inclusão e educação: Doze olhares sobre a educação inclusiva. São Paulo: Summus.

Freitas, S. N., \& Negrini, T. (2008). A identificação e a inclusão de alunos com características de altas habilidades/superdotação: Discussões pertinentes. Revista Educação Especial, Santa Maria, 32, 273-284.

http://www.ufsm.br/revistaeducacaoespecial

Gasque, K. G. D., \& Tescarolo, R. (2004). Sociedade da aprendizagem: Informação, reflexão e ética. Ciência da Informação, 33, 35-40. http://dx.doi.org/10.1590/S0100-19652004000300005

Garcia, C. M. (1999). Formação de professores: Para uma mudança educativa. Porto: Porto Editora.

Guimarães, T. G. (2007). Avaliação psicológica de alunos com altas habilidades. In: D. S. de. Fleith, \& E. M. L. S. de Alencar (Eds.), Desenvolvimento de talentos e altas habilidades: Orientação a pais e professores. Porto Alegre: Artmed. 
Maia-Pinto, R. R., \& Fleith, D. S. (2004). Avaliação das práticas educacionais de um programa de atendimento a alunos superdotados e talentosos. Psicologia escolar e educacional, 8, 55-66. http://pepsic.bvs-psi.org.br/pdf/pee/v8n1/v8n1a07.pdf

Pérez, S. G. P. B. (2003). Mitos e Crenças sobre as Pessoas com Altas Habilidades: Alguns aspectos que dificultam o seu atendimento. Cadernos de Educação Especial, 22, 45-59.

Pérez, S. G. P. B. (2004). Gasparzinho vai à escola: Um estudo sobre as características do aluno com altas habilidades produtivo-criativo. 230 f. Dissertação (Mestrado em Educação), Porto Alegre: Faculdade de Educação, Pontifícia Universidade Católica do Rio Grande do Sul.

Piske, F. H. R. (2011). Diversidade e inclusão: O direito à educação de alunos superdotados. X Congresso Nacional de Educação-Educere-I Seminário Internacional de Representações Sociais, Subjetividade de Educação-SIRSSE, Curitiba, Champagnat, 151-161. http://educere.bruc.com.br/CD2011/pdf/4341_2306.pdf

Piske, F. H. R., \& Stoltz, T. (2012). O Desenvolvimento Afetivo de Alunos Superdotados: Uma Contribuição a partir de Piaget. Schème: Revista Eletrônica de Psicologia e Epistemologia Genéticas, 4, 149-166.

Piske, F. H. R. (2013). O desenvolvimento socioemocional de alunos com Altas Habilidades/Superdotação (AH/SD) no contexto escolar: Contribuições a partir de Vygotsky. Dissertação (Mestrado em Educação), Curitiba: Universidade Federal do Paraná.

Piske, F. H. R., \& Stoltz, T. (2013). Criatividade na escola: A necessidade de reavaliar as práticas educacionais aos alunos superdotados. In F. H. R. Piske, \& S. Bahia (Eds.), Criatividade na escola: O desenvolvimento de potencialidades, altas habilidades/superdotação (AH/SD) e talentos. Curitiba, Juruá.

Piske, F. H. R., Stoltz, T., \& Machado, J. (2014). Creative Education for Gifted Children. Creative Education, 5, $347-352$. http://www.scirp.org/journal/PaperInformation.aspx?PaperID=45206

Rech, A. J. D., \& Freitas, S. N. (2005). Uma análise dos mitos que envolvem os alunos com altas habilidades: A realidade de uma escola de Santa Maria/RS. Revista brasileira de educação especial, 11, 295-314. http://www.scielo.br/pdf/rbee/v11n2/v11n2a9.pdf

Renzulli, J. S., \& Reis, S. M. (1985). The Schoolwide Enrichment Model. Mansfield Center: Creative Learning.

da Silva, S. C., \& Aranha, M. S. F. (2005). Interação entre professora e alunos em salas de aula com proposta pedagógica de educação inclusiva. Revista brasileira de educação especial, 11, 373-394. http://www.scielo.br/pdf/rbee/v11n3/v11n3a05.pdf

Stoltz, T., \& Piske, F. H. R. (2012). Vygotsky e a questão do talento e da genialidade. In L. C. Moreira, \& T. Stoltz (Eds.), Altas habilidades/superdotação, talento, dotação e educação. Curitiba: Juruá.

Tunes, E. (2003). Por que falamos de inclusão? Revista linhas críticas, 9, 5-12.

Virgolim, A. M. R. (2003). A criança superdotada e a questão da diferença: Um olhar sobre suas necessidades emocionais, sociais e cognitivas. Linhas críticas: revista da faculdade de educação da UnB, 9, 13-31. http://www.fadinhadalua.hpg.ig.com.br/a crianca sd.pdf

Wechsler, S. M. (1998). Criatividade: Descobrindo e encorajando. São Paulo: Psy.

Winner, E. (1998). Crianças superdotadas: Mitos e realidades. Porto Alegre: Artes Médicas.

Winner, E. (2000). The Origins and Ends of Giftedness. American Psychologist, 55, 159-169. http://dx.doi.org/10.1037/0003-066X.55.1.159 